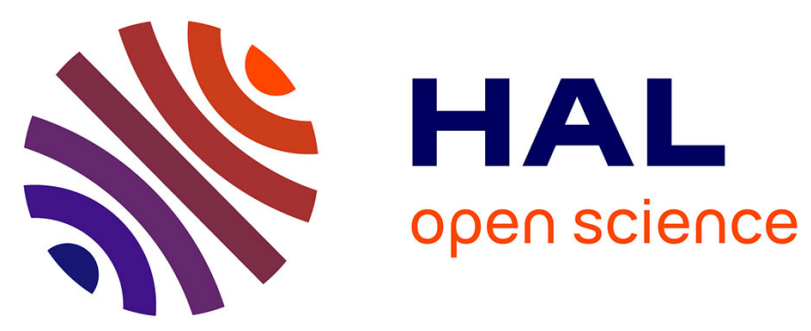

\title{
From land and sea, long-term data reveal persistent humpback whale (Megaptera novaeangliae) breeding habitat in New Caledonia
}

Solène Derville, Leigh Gabriela Torres, Rémi Dodémont, Véronique Perard, Garrigue Claire

\section{To cite this version:}

Solène Derville, Leigh Gabriela Torres, Rémi Dodémont, Véronique Perard, Garrigue Claire. From land and sea, long-term data reveal persistent humpback whale (Megaptera novaeangliae) breeding habitat in New Caledonia. Aquatic Conservation: Marine and Freshwater Ecosystems, 2019, 10.1002/aqc.3127 . hal-02962096

\section{HAL Id: hal-02962096 https://hal.sorbonne-universite.fr/hal-02962096}

Submitted on 19 Oct 2020

HAL is a multi-disciplinary open access archive for the deposit and dissemination of scientific research documents, whether they are published or not. The documents may come from teaching and research institutions in France or abroad, or from public or private research centers.
L'archive ouverte pluridisciplinaire HAL, est destinée au dépôt et à la diffusion de documents scientifiques de niveau recherche, publiés ou non, émanant des établissements d'enseignement et de recherche français ou étrangers, des laboratoires publics ou privés. 


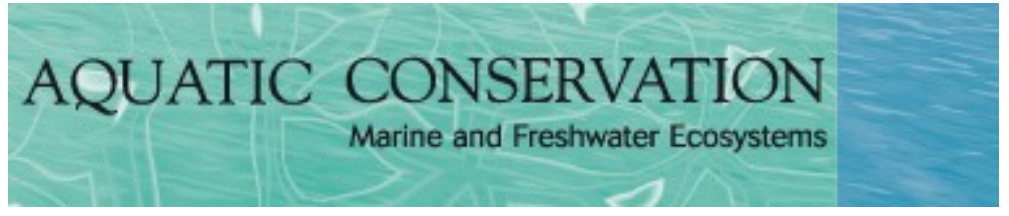

\section{From land and sea, long-term data reveal persistent humpback whale breeding habitat in New Caledonia}

\begin{tabular}{|r|l|}
\hline Journal: & Aquatic Conservation: Marine and Freshwater Ecosystems \\
\hline Manuscript ID & AQC-18-0307.R1 \\
\hline Wiley - Manuscript type: & Research Article \\
\hline Author: & n/a \\
\hline $\begin{aligned} & \text { Complete List of Authors: } \text { Derville, Solène; Institut de recherche pour le developpement Nouvelle- } \\
& \text { Caledonie, UMR Entropie; COMUE Sorbonne Universites, ED129; Oregon } \\
& \text { State University, Marine Mammal Institute; Opération Cétacés } \\
& \text { Torres, Leigh; Oregon State University, Marine Mammal Institute } \\
& \text { Dodémont, Rémi; Opération Cétacés } \\
& \text { Perard, Véronique; Opération Cétacés } \\
& \text { Garrigue, Claire; Institut de recherche pour le developpement Nouvelle- } \\
& \text { Caledonie, UMR Entropie; Opération Cétacés }\end{aligned}$ \\
\hline $\begin{array}{r}\text { Broad habitat type } \\
\text { (mandatory) select 1-2: }\end{array}$ & coastal < Broad habitat type, lagoon < Broad habitat type \\
\hline $\begin{array}{r}\text { General theme or application } \\
\text { (mandatory) select 1-2: }\end{array}$ & $\begin{array}{l}\text { habitat mapping < General theme or application, recovery < General } \\
\text { theme or application, monitoring < General theme or application }\end{array}$ \\
\hline $\begin{array}{r}\text { Broad taxonomic group or } \\
\text { category (mandatory, if }\end{array}$ & mammals < Broad taxonomic group or category \\
relevant to paper) select 1-2: & \\
\hline $\begin{array}{r}\text { Impact category (mandatory, } \\
\text { if relevant to paper) select 1- } \\
2:\end{array}$ & recreation < Impact category, shipping < Impact category \\
\hline & \\
\hline
\end{tabular}

\section{SCHOLARONE" \\ Manuscripts}




\title{
From land and sea, long-term data reveal persistent humpback whale (Megaptera novaeangliae) breeding habitat in New Caledonia
}

\author{
Solène Derville ${ }^{1,2,3,4 *}$, Leigh G. Torres ${ }^{3}$, Rémi Dodémont ${ }^{4}$, Véronique Perard ${ }^{4}$, Claire Garrigue $^{1,4}$ \\ ${ }^{1}$ UMR ENTROPIE (IRD, Université de La Réunion, CNRS), New Caledonia. \\ ${ }^{2}$ Sorbonne Université, Collège Doctoral, ED129, France. \\ ${ }^{3}$ Geopsatial Ecology of Marine Megafauna Lab, Marine Mammal Institute, Department of Fisheries and \\ Wildlife, Oregon State University, Newport, Oregon, USA. \\ ${ }^{4}$ Opération Cétacés, New Caledonia. \\ *Corresponding author: solene.derville@ird.fr
}

\section{$1 \quad$ ABSTRACT}

2 1. Long-term monitoring is a prerequisite to understand and protect long-lived species such as 3 cetaceans. In New Caledonia, South Pacific, an endangered subpopulation of humpback whales 4 (Megaptera novaeangliae) seasonally congregates for mating and nursing during the austral 5 winter. For more than two decades, dedicated surveys have been conducted at sea and from land to monitor humpback whale presence in a coastal breeding site, the South Lagoon.

2. Methods were developed to investigate space use patterns and their temporal variations over the long term using a joint dataset of boat-based and land-based observations (1995 - 2017). A total of 2,651 humpback whale groups were observed, including 1,167 from land and 1,484 at sea (of which $30 \%$ were initially detected by the land-based observers).

3. Humpback whales displayed a persistent space use pattern over this 23 year period, consistent social composition over the years, and an increase of the group encounter rates from land and at sea. The core area of use by humpback whales was characterized in the austral winter by stable and relatively low sea surface temperature $\left(22^{\circ} \mathrm{C}\right)$. Whales consistently occupied nearshore waters from 10 to $200 \mathrm{~m}$ deep and open to the ocean. Waters surrounded by dense coral reefs were avoided. 
4. Although humpback whale distribution patterns were persistent and occurrence was found to increase over two decades, a mismatch between humpback whale critical habitat and marine protected areas was revealed. In the context of growing anthropogenic pressure from tourism and industrial development, these findings should be incorporated into local management efforts to protect the endangered Oceania humpback whale in one of its main breeding sites.

\section{KEYWORDS}

Coastal, habitat mapping, lagoon, mammals, monitoring, recovery, recreation, shipping

\section{INTRODUCTION}

Industrial whaling of the $19^{\text {th }}$ and $20^{\text {th }}$ century greatly impacted humpback whale (Megaptera novaeangliae) populations worldwide (Rocha, Clapham, \& Ivashchenko, 2015). Today, humpback whale populations globally show encouraging signs of recovery, yet are variable from one population to the other (Thomas, Reeves, \& Brownell, 2015). As humpback whales are now facing the cumulative effects from threats of pollution, vessel traffic, entanglement, noise or tourism resulting from increasing anthropogenic activities (Avila, Kaschner, \& Dormann, 2018), there is a need to monitor populations at a local scale. Understanding the trends in distribution, habitat use and dynamics of populations is essential to implementing appropriate local conservation measures, and ensure the species recovery as a whole.

34 The slow breeding rate (i.e. generation time $21.5 \mathrm{yr}$, Taylor, Chivers, Larese, \& Perrin, 2007) and long life-span (i.e. 95 yr, Chittleborough 1965; Gabriele, Lockyer, Straley, Jurasz, \& Kato, 2010) of humpback whales warrants long-term datasets in order to detect potential trends in distribution and population demographics. Thereby, monitoring programmes conducted over several decades have greatly contributed to the knowledge and protection of humpback whales, for example in Glacier Bay (Gabriele et al., 2017; Pierszalowski et al., 2016) or the Gulf of Maine (Robbins, 2007). However, such long-term datasets are rarely available (Sydeman, Poloczanska, Reed, \& Thompson, 2015), as the high financial cost and challenging survey environment characterizing cetacean studies are obvious obstacles to the implementation of research projects over several decades (Simmonds \& Eliott, 2009). Also, once actually collected, long-term datasets often constitute data processing and statistical challenges, particularly due to protocol mismatches (Ducklow, Doney, \& Steinberg, 2009; Lindenmayer \& Likens, 2010) regarding the extent of survey effort and the evolution of methods used across several years or decades. 
46 The Oceania population of humpback whales is relatively small, has one of the slowest recovery rates 47 (Constantine et al., 2012; Jackson et al., 2015) and is still listed as "endangered" in the IUCN Red List 48 (Childerhouse et al., 2008). Humpback whales of the Oceania population feed during the austral summer 49 in the remote waters of the Southern Ocean, from the Balleny Islands to the Antarctic peninsula 50 (Albertson et al., 2018; Constantine et al., 2014; Riekkola et al., 2018; Steel et al., 2017). During the 51 austral winter, they migrate to breeding grounds in the South Pacific islands and reefs, where mating, 52 calving and nursing take place. Various degrees of subpopulation structuring have been identified across 53 this vast area (Constantine et al., 2012; Olavarría et al., 2007) and the International Whaling Commission 54 recognizes several breeding sub-stocks including BSE2 in New Caledonia, BSE3 in Tonga and BSF in 55 French Polynesia (IWC, 1998; Jackson et al., 2015). Among the widely dispersed breeding grounds 56 found across Oceania, humpback whale research has only been carried out in a few specific study sites.

57 New Caledonia is the most westerly archipelago visited by the endangered humpback whale population 58 of Oceania. Humpback whales found in this archipelago are demographically isolated and genetically 59 differentiated from the two neighbour breeding populations of eastern Australia and Tonga (Garrigue, 60 Dodemont, Steel, \& Baker, 2004; Olavarría et al., 2007). The New Caledonia South Lagoon (Figure 1) 61 is historically considered one of the main humpback whale breeding grounds known to date for this 62 subpopulation (Garrigue, Greaves, \& Chambellant, 2001). Humpback whales at this breeding site have 63 been the focus of a continuous long-term monitoring programme (Garrigue et al., 2001) initiated in the 64 mid-1990s, which has documented humpback whale presence in the South Lagoon during the austral 65 winter, with a peak of abundance after mid-August. Humpback whales in this coastal study site have 66 been consistently monitored for more than 20 years using an original protocol combining boat-based and 67 land-based observation.

68 The New Caledonia South Lagoon also concentrates several human activities that constitute liable threats 69 to whales. Active nickel mining on the mainland has induced increased maritime traffic of large cargo 70 ships, specifically in the Prony Bay where an industrial port was constructed in 2006 following the 71 development of a new hydrometallurgical process plant (Bourgogne, Derville, \& Garrigue, 2018, Figure 72 1). New Caledonia also is a leading whale watching destination among the South Pacific Islands 73 (Schaffar, Garrigue, \& Constantine, 2010; Schaffar et al., 2013; Figure 1). Since 2008, humpback whales 74 have been legally protected by the local environmental legislation that forbids deliberate disturbance, 75 specifically approaching whales closer than $50 \mathrm{~m}$ or observing whales within less than $200 \mathrm{~m}$ for over 2 76 hours (Province Sud, 2009). In addition, observations guidelines have been proposed to promote 77 responsible whale watching behaviour (Province Sud, 2018). Yet, increasing tourism and human 
78 population density (www.isee.nc) is a cause of concern in terms of disturbance and collision risks (Currie, 79 Stack, \& Kaufman, 2017; New et al., 2015; Senigaglia et al., 2016). In the South Lagoon, the number of 80 whale watching touristic operators has increased from 5 in 1995, to 24 in 2017 (Province Sud \& 81 Opération Cétacés, unpublished data). An integral marine protected area, the Merlet Reserve, was created 82 in 1970 to prevent all human activities over a $170 \mathrm{~km}^{2}$ area north-east of the South Lagoon (IUCN 83 category Ia, Figure 1). A great part of the South Lagoon is also classified as a UNESCO World Heritage 84 85 86

\section{METHODS}

\section{Study region and survey design}

New Caledonia is an archipelago located in the south-west Pacific Ocean about 1,500 km north-east of Australia (Figure 1). New Caledonia mainland, also called "Grande Terre", is surrounded by a large lagoon delimited by a 1,500 km-long barrier reef. The South Lagoon is a large shallow area (about $50 \mathrm{~m}$ deep) located south of the mainland, bounded by the Prony Bay and the Ouen Island to the north, and by two reef complexes to the south-west ("Corne Sud") and the north-east (Isle of Pines, Figure 1). The 
108 south-eastern part of this lagoon is open to the ocean and is characterized by deeper waters (reaching 600 $109 \mathrm{~m}$ deep). New Caledonia is under the influence of two main currents: the highly unstable south-eastward 110 Vauban Current (VC) flows south through the Loyalty channel bringing warm waters in winter. In 111 contrast, the south-eastward Alis Current of New Caledonia (ACNC) carries colder waters into the area 112 from the west (Figure 1; Cravatte et al., 2015; Marchesiello, Lefèvre, Vega, Couvelard, \& Menkes, 2010).

Surveys were part of a single monitoring program conducted in the South Lagoon of New Caledonia from 1995 to 2017 (except for 2004 and 2008), between the beginning of July and the end of September. Surveys were conducted in Beaufort sea-states $\leq 3$ (and avoiding heavy rain) and were simultaneously conducted at sea and from a land-based look-out located on top of the Cape N'Doua (altitude $189 \mathrm{~m}$, > $270^{\circ}$ visibility, Figure 2). Both teams could communicate at all times using Very High Frequency (VHF) radios. A land-based team composed of one to five trained observers scanned the study area and detected whales up to $36 \mathrm{~km}$ from the Cape. A few areas close to the coast and within the Prony Bay were masked from the Cape (Schaffar et al. 2013; Figure 2b) and their extent was measured using a theodolite (a rotating telescope for measuring vertical and horizontal angles to accurately locate positions at the sea surface with a simple trigonometric calculation). The boat-based team was composed of three to five trained observers in a $6 \mathrm{~m}$ rigid-hulled inflatable boat moving at $14 \mathrm{~km} \cdot \mathrm{h}^{-1}$ on average. Surveys followed a haphazard sampling regime (Corkeron et al., 2011), with effort dependent on weather conditions and focused on waters accessible on a daily basis from the Prony Bay.

\section{Group occurrences and social composition}

Data processing and statistical modelling was performed with the R software version 3.2.5 (R Core Team, 2016) and geographical data visualization was performed using QGIS v.2.14. (QGIS Development Team, 2016).

For each encounter, geographic position, time, social group type and minimum-maximum group size were recorded. A whale group was defined by a unique detection source, (i.e. the team that first detected the group, either land-based, boat-based or external source such as a whale-watching operator), and may have been subsequently followed by both the land- and the boat-based teams. Encounters were considered independent events, as repeated observations of the same individual whale within a survey day rarely occurred (Derville, Torres, \& Garrigue, 2018). The geographic position of groups followed at sea was recorded in latitude-longitude using an on-board GPS, whereas groups only followed from land were located either with a precise latitude-longitude position in years where a theodolite was used (51\% of observations), or using a grid of 1 nautical mile resolution (latitude-longitude was subsequently 
139 extracted as the centre of the grid-cell the whale group was located in; $32 \%$ of observations), or by a 140 simple textual description of the location (latitude-longitude was subsequently extracted in a GIS 141 interface based on these descriptions: https://explorateur-carto.georep.nc/; 17\% of observations).

142 The influence of external factors on the detection of whales from land and at sea was compared. Daily 143 rainfall (in mm) and mean wind conditions (in knots) recorded between 1995 and 2009 were retrieved from a weather station based at the Cape N'Doua (22 $23^{\prime} 24^{\prime \prime} 166^{\circ} 55^{\prime} 30^{\prime \prime}$, Meteo France). The effect of rainfall and wind strength on the number of groups observed at sea or detected from land was assessed with sequential GLMs. The daily number of groups observed or detected was modelled with a Poisson GLM as a function of time on effort, year and Julian day of year. Then, the residuals from this regression were modelled as a function of rainfall (square-root transformed) and wind strength using a linear Gaussian regression.

The group encounter rates were calculated separately from land and at sea, as the number of groups of whales observed per hour of survey effort conducted during each day. In addition, social group types observed at sea were defined as: groups of three adults, groups of four adults, competitive groups, female with calf, female with calf followed by a single escort, female with calf followed by a competitive group, pairs, singletons, and singers. From land, solitary singers could not be differentiated from singletons, and groups of three or more adults were pooled in the same category. The proportion of social group types observed from land and at sea was calculated for each year. The effect of the observation platform (land or sea) and time (breeding seasons from 1995 to 2017) on the proportion of social group types was tested with beta regressions using the betareg $\mathrm{R}$ package (version 3.1-0).

\section{Spatial distribution and habitat use}

Quantifying survey effort at sea - The distribution of survey effort was estimated annually and separately for boat-based and land-based teams. From 2003 to 2017, effort was estimated from boat GPS tracklines recorded at one position per minute (about one position every $230 \mathrm{~m}$ for a boat moving at 14 $\mathrm{km} \cdot \mathrm{h}^{-1}$ ). Tracklines were segmented into on-effort (times when the boat-based team was actively searching for whales) and off-effort sections (times when the boat was engaged in a focal follow and was not vigilant to the detection of another group). Effort was estimated seasonally over $500 \times 500 \mathrm{~m}$ resolution grids. Time spent on-effort per grid cell was calculated, rather than distance travelled, to account for variable boat speed. To account for detection distance spanning further than the dimensions of a grid cell (average detection distance $2 \mathrm{~nm}$, Garrigue pers. obs.), a density surface of effort was derived from discrete boat GPS on-effort positions. Per breeding season, GPS tracks were projected in a 
170 UTM coordinate system and a density surface of effort was estimated with a 2-dimension Local 171 Polynomial Regression (LOESS; span =0.005).

172 From 1995 to 2002, research boats were not equipped to record GPS tracklines, a common limitation in 173 marine surveys prior to the mid-2000s. An original method was developed to assess the distribution of 174 survey effort for these seven years. GPS positions recorded over each day (end and start of focal follows, 10 and acoustical sampling positions) were compiled and connected together in a chronological order, thus forming daily paths hereafter referred to as "pseudo-tracklines". These pseudo-tracklines were considered a subsample of the real tracklines followed by the research boat over the course of a day. Yearly maps of pseudo-effort were produced using a method similar to that applied to real GPS tracklines: they were interpolated at one position/min, sections off-effort were removed, and the remaining positions were smoothed with a LOESS applied with a varying bandwidth (i.e. span ranging from 0.002 and 0.02). After evaluating the quality of each smoothed trackline in comparison to maps of effort after 2003, the 0.01 bandwidth was selected to provide the most realistic estimate of pseudo-effort distribution from 1995 to 2002 (for details see Supplement S1).

Finally, yearly maps of pseudo-effort from 1995 to 2002 and yearly maps of effort from 2003 to 2017 were concatenated, hence generating a time series of 21 yearly maps of boat-based effort. Yearly maps were rescaled to [0-100], so that cells with maximum intensity across all years were attributed $100 \%$ intensity values.

Quantifying survey effort from land - The effect of the number of observers on whale detectability from land was tested with a sequential Generalized Linear Model (GLM, McCullagh \& Nelder, 1989). First, the number of groups detected from land per day was modelled as a Poisson variable, relative to time on effort, year and Julian day of year. Residuals from this regression were modelled with a Gaussian linear regression as a function of the number of observers, with values simplified to one for one observer, and two for several observers, based on preliminary tests.

Daily land-based effort was modelled per grid cell of coordinates $(x, y)$ as a logistic function of distance to the coast:

$$
\operatorname{Effort}_{\text {land }}(x, y, t)=\operatorname{Nobs} * \operatorname{Tobs}_{\text {land }}(t) * \frac{100}{1+e^{-\sqrt{d(x, y)-12}}}
$$


198 where Nobs reflected the number of observers on day $t, T_{o b} s_{\text {land }}(t)$ was the time (in hours) spent on-effort 199 at the Cape N'Doua on day $t$, and $d(x, y)$ was the distance between the grid cell of coordinates $(x, y)$ and 200 the land-based observatory (in km; for more details see Supplement S2). The logistic curve midpoint was 201 set to $12 \mathrm{~km}$ to approximate the average distance from the land-based look-out from which humpback whales were observed ( $11.3 \mathrm{~km} \pm 5.9 \mathrm{SD}$ ). Effort was set to null for grid cells further than the maximum detection distance from the land-based look-out (36 km). Finally, daily maps of land-based effort were summed together per year to produce yearly maps of land-based effort, which were subsequently rescaled to $[0,100]$, consistent with the boat-based survey effort maps.

Spatial distribution - For each year of survey, the geographic positions of humpback whale groups observed at sea were combined with that of groups observed from land but not at sea. Kernel Density Estimates (KDE, Worton, 1989) were applied to humpback whale group positions to model yearly areas of use in the South Lagoon. KDE were applied with weights associated to each group positions, to account for survey effort variability across breeding seasons. Values of survey effort intensity were extracted respectively from the yearly maps of sea- or land-based effort at the humpback whale group positions. These extracted values ranging from 0 to 100 were converted to weights ranging from 0 to 10 with an inverse function in order to downweight whale positions occurring in highly surveyed areas. Finally, weights at each whale group position were multiplied by group size to provide more weight to positions at which larger groups were observed. As group sizes were not always recorded precisely from land, weights were attributed as follows for land-based observations: 3 for a group of three of more individuals, 2 for a pair, and 1 for singletons and unidentified social group types. KDE were calculated with plug-in bandwidth selector (Hpi) then rescaled to [0-100], either with all years of data pooled together, or separately for each breeding season. In the latter case, yearly core areas of use were calculated as the $50 \%$ contour of the yearly probability surfaces. The overlap of yearly core areas of use was calculated from 1995 to 2017 to illustrate the persistence of the humpback whale distribution pattern through time.

Habitat variables - Several topographic environmental variables were collected in the study areas to characterize habitat at a $100 \mathrm{~m}$ resolution. Coastline and reef shapefiles were produced by the Millennium Coral Reef Mapping Project (version 8, Andréfouët, Chagnaud, Chauvin, \& Kranenburg, 2008). Fringing reefs (in contact with the coastlines) were removed in order to focus on barrier and intermediate patchreef complexes. Using these shapefiles, distance to the coast and distance to non-fringing reefs were calculated for each $100 \times 100 \mathrm{~m}$ cell in the South Lagoon study area as the Euclidean distance to the closest landmass (i.e. New Caledonia mainland, Ouen Island, or the Isle of Pines) and closest barrier or 
1230 patch reef complexes, respectively. Bathymetry data (DTSI, 2016) were provided at a $100 \times 100 \mathrm{~m}$ 3231 resolution and gaps in the depth raster were subsequently filled through extrapolation of satellite and 5232 aerial composite imagery (J. Lefèvre, IRD, pers. comm.). Two terrain features were derived from the 6233 bathymetry raster: seabed slope (in degrees) and seabed aspect (the orientation of the slope, in degrees).

Habitat use model - The relationship between humpback whale distribution and environmental conditions was modelled with a Generalized Additive Model (GAM, Hastie \& Tibshirani, 1990) using the R package $m g c v$ (version 1.8-23). GAMs were applied to KDE values calculated for all years of survey from 1995 to 2017. The response variable was modelled with a beta-regression log link function. Explanatory variables included: depth, distance to the coast, distance to barrier and/or patch-reef complexes, slope, and aspect. Depth and slope were log-transformed to prevent an inflated influence of outliers as recommended by Wood (2006). Pearson coefficients were calculated between environmental variables to prevent collinearity (control that $r<0.5$ for all variables). Smoothed effects of explanatory variables in the GAM were optimized by Restrictive Maximum Likelihood (REML) and cubic smoothing splines with basis size limited to 5 to prevent overfitting. The descriptive performance of models was assessed through the computation of the proportion of deviance explained (Guisan \& Zimmermann, 2000). The deviance explained (\%) was calculated from the null deviance (deviance for a model with just a constant term) minus the residual deviance (deviance of the fitted model with explanatory terms). Partial dependence plots were produced to visualize the effect of one variable while all others were held constant at their mean (Friedman, 2001).

Sea Surface Temperature dynamic patterns - Monthly sea surface temperature (SST) was obtained to estimate the mean thermal conditions in the area during the austral winter. SST was obtained from the National Aeronautics and Space Administration (NASA) Multi-scale Ultra-high Resolution SST (MURSST) with a $1 \mathrm{~km}$ resolution from 2002 to 2017 (jplMURSST41, http://coastwatch.pfeg.noaa.gov/erdaap/). Average SST and associated coefficients of variation were calculated within and across seasons, and mapped over the study region.

\section{RESULTS \\ Survey from two platforms}

Across 21 years of study from 1995 to 2017, 807 days were spent on survey at sea and 790 from land (Table 1). On average, seasonal surveys covered 38.4 \pm SD 9.5 days at sea and 37.6 \pm SD 9.9 from land. Most of the survey effort was conducted simultaneously by both teams, on land and at sea, totalling 714 
260 days of survey in common over the study period. As a result, the team at sea was assisted by the land based observers during $88 \%$ of the days of survey.

The land-based team followed 2,021 groups of humpback whales (96.2 \pm SD 60.2 per year), of which 1,167 (57.8\%) were not followed by the boat-based team (Figure 2, Table 1). The boat-based team followed 1,484 groups (70.7 \pm SD 33.4 per year), of which $30.2 \%$ were originally detected by the landbased team who communicated the position through VHF.

The number of observers from land varied between 1 and 5 (mean $=2.0 \pm \mathrm{SD} 0.9$, number reported for 737 survey days out of 790), and was greater than 1 in $64 \%$ of survey days. The number of humpback whale groups detected from the Cape N'Doua was significantly higher when more than one observer was surveying. A null model was created to account for the effect of year, Julian day of year and duration of survey effort, on the daily number of groups detected from land. The residuals of this null model were significantly affected by the number of observers (GLM: t-value $=7.1, p<0.001)$. On average, $2.0 \pm$ SD 1.3 groups were observed when one observer was present, against $2.7 \pm$ SD 2.6 with several observers.

Between 1995 and 2009, wind and rainfall were measured over 453 days of survey. Wind strength varied from 4 to 27 knots (median $=13.6$ knots; mean $=14.1 \pm \mathrm{SD} 4.8$ knots) and daily rainfall varied from 0 to $61 \mathrm{~mm}$ (median $=0 \mathrm{~mm}$; mean $=1.2 \pm \mathrm{SD} 4.0 \mathrm{~mm}$ ). A null model was produced to relate the daily number of groups detected from land, to year, Julian day of year and duration of survey effort. The residuals of this null model were not significantly affected by rainfall (GLM: $t$-value $=0.4, p=0.7$ ) nor wind strength $(\mathrm{GLM}$ : $\mathrm{t}$-value $=1.6, \mathrm{p}=0.1)$. Among these 453 days, 412 days were surveyed at sea. A null model was produced to relate the daily number of groups observed at sea, to year, Julian day of year and duration of survey effort. The residuals of this null model were not significantly affected by rainfall (GLM: $\mathrm{t}$-value $=0.2, \mathrm{p}=0.8)$, but showed a small significant effect of wind strength $(\mathrm{GLM}$ : $\mathrm{t}$-value = $2.3, \mathrm{p}=0.02$ ). The number of groups observed at sea decreased with stronger winds.

\section{Occurrence and social composition}

In total, 2,651 independent whale groups were observed from land and at sea (Figure 2), with a maximum number of occurrences observed in 2007 ( $n=264$; Table 1). When accounting for survey effort per day, the mean group encounter rates showed an increasing trend from 1995 to 2017, both at sea (Figure 3a), and from land (Figure 3c). Both platforms showed a very similar trend, notably with a steeper increase between 2005 and 2011, a low group encounter rate in 2014 ( $<0.3$ groups per hour of survey), and a plateau with a slight decrease after 2012. 
290 Social group types typical of a humpback whale breeding ground were observed at sea across all years: 291 maternal females with a calf, competitive groups and singers (Table 2, Figure 3b). A larger proportion 5292 of group types remained unidentified by land-based observers $(29.8 \% \pm 20.1)$ compared to observers at 293 sea $(1.7 \% \pm 2.3$, Figure $3 \mathrm{~d})$, as noted in a beta-regression relating the proportion of unidentified groups 294 to platform ( $\mathrm{z}$-value $=7.3, \mathrm{p}<0.0001)$.

Combined together, the proportion of social group types observed from both platforms did not show any linear trends from 1995 to 2017. This analysis included groups with calf (mother-calf pairs, mother-calf pairs with escort or competitive groups; beta-regression: $\mathrm{z}$-value $=1.2, \mathrm{p}=0.2$ ), groups of adults (betaregression: $\mathrm{z}$-value $=1.7, \mathrm{p}=0.8$ ), pairs (beta-regression: $\mathrm{z}$-value $=-0.2, \mathrm{p}=0.8$ ), singleton (including singers; beta-regression: $\mathrm{z}$-value $=-1.9, \mathrm{p}=0.05$ ), and unidentified social types (beta-regression: $\mathrm{z}$-value $=1.9, \mathrm{p}=0.05)$.

\section{Spatial distribution}

A core area of use for humpback whales was identified outside the Prony Bay, between the two main reef complexes of the South Lagoon, the Corne Sud to the south-west and the Merlet reserve to the northeast (Figure 4a). Humpback whales were also found to display a noteworthy use of the inner waters of the Prony Bay. Yearly core areas of use showed a strong overlap, in a zone located at the centre of the study area (Figure 4 b). Persistent use was found over a $77 \mathrm{~km}^{2}$ zone that was included in yearly core areas of use for at least 10 years (Figure $4 \mathrm{~b}$ ). There was no overlap between the core area of use and the Merlet Reserve ( $0 \%$ coverage, Figure 4a, Table 3 ), and only a limited overlap with the UNESCO World Heritage zone (38\% coverage). On the other hand, the Province Park included $100 \%$ of the core and general areas of humpback whale use (Table 3).

\section{Habitat use}

Depth $\left(\mathrm{edf}=3.8, \mathrm{Chi}^{2}=575.7, \mathrm{p}<0.001\right)$, distance to coast $\left(\mathrm{edf}=2.0, \mathrm{Chi}^{2}=1081.2, \mathrm{p}<0.001\right)$, distance to barrier and patch reef complexes ( $\left.\mathrm{edf}=1.9, \mathrm{Chi}^{2}=63.3, \mathrm{p}<0.001\right)$, and seabed slope $\left(\mathrm{edf}=2.0, \mathrm{Chi}^{2}\right.$ $=145.3, \mathrm{p}<0.001)$ were significant predictors of humpback whale habitat in the South Lagoon (GAM, deviance explained $=36.6 \%$ ). The occurrence of humpback whales increased with proximity to coast in the South Lagoon. Humpback whales were less frequently found in close contact to coral reef complexes $\left(<2 \mathrm{~km}\right.$ from a reef). Seabed slopes of more than $2^{\circ}$ were favoured, though there are few high values of slope in the dataset. Humpback whale occurrence patterns displayed a complex relationship with respect to depth: both very shallow waters $(10 \mathrm{~m})$ and relatively deep waters $(50-100 \mathrm{~m})$ were predicted to be 
320 suitable habitats. The modelled probability of presence reached a plateau when depth was greater than $321100 \mathrm{~m}$ indicating that deeper waters may also be suitable, although there were little data collected at such 322 depth within the South Lagoon, as revealed by the rug plot associated to this variable (Figure 5).

SST patterns averaged over the study area from 2002 to 2017 revealed that waters located in the northwestern limit of the study area near Ouen Island were consistently colder during the winter (Figure 6). The core area of use for humpback whales was characterized by average temperatures between $22^{\circ} \mathrm{C}$ and $22.4^{\circ} \mathrm{C}$. Moreover, SST in the core area of use for humpback whales was the most stable in the winter (within and between breeding seasons), in contrast with the eastern coast of New Caledonia and the Isle of Pines under influence of the Vauban current (Figure 1). Indeed, standard deviation of the MURSST in winter was highest in the north-eastern part of the study area (Figure 6).

\section{DISCUSSION}

This study provides information on the long-term occurrence patterns of an endangered population of humpback whales seasonally present in the New Caledonia South Lagoon. Occurrence of humpback whales in the South Lagoon was found to have increased between 1995 and 2017. The distribution and social composition of the population visiting the area in the austral winter, between July and September, was stable across years. Females with a calf were observed every year, as well as other social group types typical of humpback whale breeding grounds, such as competitive groups. Persistent habitat use patterns were robustly modelled using two complementary long-term datasets extending over more than two decades. However, a mismatch was found between habitats favoured by humpback whales and currently existing marine protected areas in the South Lagoon.

Although many of the most studied cetacean species live in coastal waters, the use of land-based lookouts for the purpose of scientific research is uncommon. Indeed, many cetacean studies favour the collection of biological samples and photographs that cannot be collected from land but that provide valuable information on individuals (e.g. Garrigue et al., 2004) for studying behaviour, life history and demography. In addition, unless the cetaceans are very close to shore (e.g. Stockin, Weir, \& Pierce, 2006), group sizes and behaviours are generally more accurately measured during focal follows at sea than from land. Here, many of the groups observed only from land were not ascribed a social type, and groups of more than three individuals were all pooled in the same category, with no distinction of group size or competitive behaviour. On the other hand, compared to surveys at sea, land-based surveys have the great advantages of being cheaper, less technically challenging and not impactful for animals (Aragones, 
1350 Jefferson, \& Marsh, 1997; Giacoma, Papale, \& Azzolin, 2013). They have been successfully applied to 351 monitor the impact of whale watching and maritime traffic (e.g. Avila, Correa, \& Parsons, 2015; Schaffar 5352 et al., 2013; Stamation, Croft, Shaughnessy, Waples, \& Briggs, 2010; Sullivan \& Torres, 2018). Here, 353 the land-based team had greater spatial and temporal detectability of whales than the boat-based observers, as the team could survey a larger extent, and was capable of following several groups at the same time. For instance, the Merlet integral reserve was consistently surveyed by the land-based team throughout the study period, whereas the research boat was only permitted to enter the area during half of the study years (1996-2008 and 2015, Figure 2). Similarly, land-based lookouts have been used in support of boat-based survey teams in other parts of the world to increase the detection of smaller cetacean species (e.g. Risso dolphin, Grampus griseus, Hartman et al., 2014). Considering the relatively low cost of adding a team on land when a boat-based monitoring programme is already in place, this study supports the synergic advantages of combining these two platforms of observation when a landbased look-out is available in the study area.

In recent decades, ecological research methods have undergone tremendous technological advances. One indirect drawback is the potential to alter the consistency of survey protocols used in long-term studies. In the South Lagoon humpback whale monitoring program, as in many marine long-term studies, the incorporation of onboard GPS tracking has greatly improved the quality of spatial data collected. Indeed, tracklines represent an essential piece of information to spatially quantify survey effort (Derville, Torres, Iovan, \& Garrigue, 2018), but were only recorded from 2003 onwards in this study. In order to maintain the integrity of the 20-year long dataset collected in the South Lagoon, survey effort at sea was approximated using "pseudo-tracklines" (see Supplement S1). This method was based on acoustic sampling and group locations, but it may be applied to any 'location data' recorded during a day of survey at sea (e.g. environmental sampling locations). Using this approach on this long-term dataset, a general trend of increasing group encounter rates was identified throughout the study period, both at sea and from land. Anomalous years in the trend may be explained by slight changes in the seasonality of survey effort, such as in 2014 when the mid-August breeding season peak was exceptionally not surveyed. Combining several lines of evidence, this study supports the ongoing recovery of the New Caledonia endangered humpback whale subpopulation.

Maternal females, competitive groups and singers were almost constantly observed across breeding seasons, reflecting consistent mating and nursing activity in the South Lagoon. Although calving of humpback whales has never been directly observed in the South Lagoon, as in the majority of the breeding sites worldwide (Faria, DeWeerdt, Pace, \& Mayer, 2013), it is assumed to occur within or close 
382 to this breeding ground. Indeed, calves with newborn traits (pale flank pigmentation, small size and furled 383 dorsal fin; Cartwright \& Sullivan, 2009; Irvine, Thums, Hanson, Mcmahon, \& Hindell, 2017) are regularly observed in the South Lagoon (Derville, Torres, \& Garrigue, 2018). Overall, the core area of humpback whale distribution was located at the centre of the study area, bounded by the coast and two large reef complexes. Although humpback whales are observed sporadically in coastal waters and lagoons all over the New Caledonian archipelago (Derville, Torres, Iovan, et al., 2018; Garrigue \& Gill, 1994), the South Lagoon appears to be the most visited coastal breeding site (Garrigue et al., 2001). This aggregation is likely to be at least partially driven by social factors (Clapham \& Zerbini, 2015), but it may also be linked to environmental conditions specific to this area. In the core area of humpback whale distribution, SST averaged $22-22.5^{\circ} \mathrm{C}$ in the austral winter, a temperature that is well within the preferential SST range identified by Rasmussen et al. (2007). The SST in the core area of use was also relatively stable both within and between years, compared to the surrounding open ocean. Spatiotemporal predictability of resources, or suitable environmental conditions, is an important driver of spatial distribution in the ocean (Lambert et al., 2016; Scales et al., 2014). The persistence of temperature conditions in the South Lagoon could contribute to its attractiveness for maternal females that can rely on this area to provide suitable habitat to their calf.

Habitat models suggest a preference for nearshore shallow waters in accordance with other humpback whale breeding grounds around the world (Bortolotto, Danilewicz, Hammond, Thomas, \& Zerbini, 2017; Cartwright et al., 2012; Lindsay et al., 2016; Martins et al., 2001; Oviedo \& Solís, 2008; Smith et al., 2012; Trudelle et al., 2018). However, the modelled habitat relationships also suggested that whales may be found in the relatively deep waters in the southern part of the study area (about $200 \mathrm{~m}$ deep). The modelled occurrence was relatively high in these conditions but was associated with a strong uncertainty. Nevertheless, this result is consistent with satellite tracking of individual humpback whales from this region that moved between the South Lagoon and several seamounts located south of the Isle of Pines (i.e. Torch Bank and Antigonia seamount, Garrigue, Clapham, Geyer, Kennedy, \& Zerbini, 2015). Antigonia seamount is now known as an important breeding ground (Derville, Torres, \& Garrigue, 2018; Garrigue et al., 2017). Frequent movements between these hotspots (Garrigue et al., 2017; Orgeret, Garrigue, Gimenez, \& Pradel, 2014) may explain the relatively high occurrence of whales in the southernmost part of the South Lagoon.

The relationship to coral reef complexes was not linear and showed that humpback whales occurred in waters neighbouring reefs $(3-4 \mathrm{~km})$ but not directly next to them. In contrast, distance to coral reef was not identified as a primary factor influencing humpback whale distribution in other breeding grounds that 
1414 include large reef extents (e.g. Great Barrier Reef, Smith et al. 2012), except when considering maternal 415 females only (e.g. Vava'u, Tonga, Lindsay et al. 2016). In Vava'u, females with a calf preferentially used 416 the sheltered waters inside the reef complexes, whereas groups with no calf occupied deeper waters on 417 the external slope. In the South Lagoon, groups with and without a calf do not segregate with respect to 418

reef complexes of the South Lagoon appeared to be avoided by all social group types. Indeed, dense and shallow reef areas form intricate networks that have the potential to trap large whales. Also, seabed terrain and depth are known to affect sound propagation (Mercado III \& Frazer, 1999), hence potentially constraining the spatial distribution of singing males. Rugged (Pack et al., 2017) and/or shallow habitats (Mercado III \& Frazer, 1999), such as that of the South Lagoon reef complexes could be less suitable for acoustic communication, and therefore less attractive for singers and their audience. Based on these distributional preferences, the Merlet integral reserve (IUCN category Ia) was rarely used by humpback whales in the New Caledonia South Lagoon. The UNESCO World Heritage Zone also mostly mismatched the humpback whale core area of use. The Province Park did include the area of humpback whale use, but only offers a very low level of protection. As human activities such as maritime traffic and tourism are not regulated within the Park, humpback whales potentially remain at risk of disturbance and collisions. There is no marine protected area specifically dedicated to the mitigation of anthropogenic impacts on cetaceans in New Caledonia. Moreover, it appears that the existing conservation areas with high levels of protection in the South Lagoon do not overlap with critical habitats of this endangered subpopulation of humpback whales.

Group encounter rates measured per year from both platforms of observations support the increase in the population sizes that was independently estimated from capture-recapture using photo-identification and genotype data (C. Garrigue, Albertson, \& Jackson, 2012; Jackson et al., 2015; Orgeret et al., 2014). However, this encouraging sign of recovery of a humpback whale subpopulation in Oceania should be put in perspective with emerging threats in the region. Coastal breeding grounds are particularly exposed to increasing anthropogenic threats resulting from touristic and industrial activities. Whale watching activities are growing in popularity (O’Connor, Campbell, Knowles, Cortez, \& Grey, 2009), and are an increasing source of income in the Pacific Islands. Although observation guidelines exist for the region (Province Sud, 2018), the ever increasing number of boats in the area during the winter is a current cause of concern (Bourgogne et al., 2018). Land-based whale watching exists in a few regions of the world (e.g. Cook Islands, South Africa, Australia, O'Connor et al. 2009) and could be further promoted in New Caledonia as an alternative to boat-based tours. Moreover, the identification of the core area of humpback 
whale use in the South Lagoon constitutes a first step towards the mitigation of collision risks around shipping lanes (Dransfield et al., 2014; Pirotta, New, \& Marcoux, 2018; Redfern et al., 2013). As the New Caledonian subpopulation of humpback whales progressively recovers, private and public boat drivers should be educated about risks to whales and where they are likely to be distributed to anticipate increased collision risks in the areas of greatest humpback whale use. Efforts to prevent collisions should particularly target females with a calf as these groups are most vulnerable to disturbance and ship strikes (Cartwright et al., 2012; Laist, Knowlton, Mead, Collet, \& Podesta, 2001; Lammers, Pack, \& Davis, 2007), and also favour the sheltered waters closest to the coast where maritime traffic is the most intense in the South Lagoon (Derville, Torres, \& Garrigue, 2018). Finally, as humpback whale conservation was identified as one of the main objectives for the South Lagoon Province Park (Province Sud, 2013), we suggest that future management plans and zoning explicitly incorporate seasonal regulations of boat traffic and recreational activities within their core area of use. Hence, by using a long-term monitoring approach, this study provides important information to ensure the continued recovery of an endangered subpopulation of humpback whales.

\section{ACKNOWLEDGMENTS}

We thank the volunteers who participated in the fieldwork since 1995. Our acknowledgments go to D. Boillon, C. Bonneville, H. Bourgogne, J. Burgess, M. Chambellant, M. Oremus, M. Poupon, and A. Schaffar. Financial support was partly provided by the Comité Consultatif Coutumier Environnemental, Fondation d'Entreprises Total, International Fund for Animal Welfare, Fondation Nature et Découvertes,

Province Sud, Total Pacifique, Vale S.A and the World Wildlife Fund. This study was carried out following the marine mammal treatment guidelines of the Society for Marine Mammalogy. Fieldwork was undertaken under permits issued by the Environment Department of the Province Sud of New Caledonia.

\section{REFERENCES}

Albertson, G. R., Friedlaender, A. S., Steel, D. J., Aguayo-Lobo, A., Bonatto, S. L., Caballero, S., ... Baker, C. S. (2018). Temporal stability and mixed-stock analyses of humpback whales (Megaptera novaeangliae) in the nearshore waters of the Western Antarctic Peninsula. Polar Biology, 41(2), 323-340. https://doi.org/10.1007/s00300-017-2193-1

Andréfouët, S., Chagnaud, N., Chauvin, C., \& Kranenburg, C. J. (2008). Atlas of French Overseas Coral Reefs. http://umr-entropie.ird.nc/index.php/home/ressources/mcrmp. Accessed February 
$1476 \quad 2016$.

Aragones, L. V, Jefferson, T. A., \& Marsh, H. (1997). Marine Mammal Survey Techniques Applicable In Developping Countries. Asian Marine Biology, 14, 15-39. Retrieved from https://books.google.fr/books?hl=fr\&lr=\&id=rHVFBAAAQBAJ\&oi=fnd\&pg=PA15\&dq=cetacea $\mathrm{n}+$ whale + dolphin + abundance\&ots $=\mathrm{bXwax} Y$ XhMf\&sig $=$ B8FaHSRBM4BKqAVWX1fZkClBm1s

Avila, I. C., Correa, L. M., \& Parsons, E. C. M. (2015). Whale-Watching Activity in Bahía Málaga, on the Pacific Coast of Colombia, and its Effect on Humpback Whale (Megaptera Novaeangliae) Behavior. Tourism in Marine Environments, 11(1), 19-32. https://doi.org/10.3727/154427315X14398263718394

Avila, I. C., Kaschner, K., \& Dormann, C. F. (2018). Current global risks to marine mammals: Taking stock of the threats. Biological Conservation, 221(February), 44-58. https://doi.org/10.1016/j.biocon.2018.02.021

Bortolotto, G. A., Danilewicz, D., Hammond, P. S., Thomas, L., \& Zerbini, A. N. (2017). Whale distribution in a breeding area: spatial models of habitat use and abundance of western South Atlantic humpback whales. Marine Ecology Progress Series, 585, 213-227. Retrieved from https://doi.org/10.3354/meps 12393

Bourgogne, H., Derville, S., \& Garrigue, C. (2018). Étude du trafic maritime dans le Grand Lagon Sud afin d'apprécier les risques de dérangement et de collision pour la population de baleines à bosse de Nouvelle-Calédonie. Rapport non publié pour le CCCE.

Cartwright, R., Gillespie, B., Labonte, K., Mangold, T., Venema, A., Eden, K., \& Sullivan, M. (2012). Between a Rock and a Hard Place : Habitat Selection in Female-Calf Humpback Whale (Megaptera novaeangliae) Pairs on the Hawaiian Breeding Grounds. PLOS One, 7(5), e38004. https://doi.org/10.1371/journal.pone.0038004

Cartwright, R., \& Sullivan, M. (2009). Behavioral ontogeny in humpback whale (Megaptera novaeangliae) calves during their residence in Hawaiian waters. Marine Mammal Science, 25(3), 659-680. https://doi.org/10.1111/j.1748-7692.2009.00286.x

Childerhouse, S., Jackson, J., Baker, C. S., Gales, N., Clapham, P. J., \& Brownell, R. J. (2008). Megaptera novaeangliae Oceania subpopulation. The IUCN Red List of Threatened Species 2008: e.T132832A3463914. https://doi.org/10.2305/IUCN.UK.2008.RLTS.T132832A3463914.en.

Chittleborough, R. G. (1965). Dynamics of two populations of the humpback whale, Megaptera novaeangliae (Borowski). Marine and Freshwater Research, 16, 33-128.

Clapham, P. J., \& Zerbini, A. N. (2015). Are social aggregation and temporary immigration driving high rates of increase in some Southern Hemisphere humpback whale populations? Marine Biology, 162, 625-634. https://doi.org/10.1007/s00227-015-2610-3

Cleguer, C., Grech, A., Garrigue, C., \& Marsh, H. (2015). Spatial mismatch between marine protected areas and dugongs in New Caledonia. Biological Conservation, 184, 154-162. https://doi.org/10.1016/j.biocon.2015.01.007

Constantine, R., Jackson, J. A., Steel, D., Baker, C. S., Brooks, L., Burns, D., ... Garrigue, C. (2012). Abundance of humpback whales in Oceania using photo-identification and microsatellite genotyping. Marine Ecology Progress Series, 453, 249-261. https://doi.org/10.3354/meps09613

Constantine, R., Steel, D., Allen, J., Anderson, M., Andrews, O., Baker, C. S., ... Ward, J. (2014). Remote Antarctic feeding ground important for east Australian humpback whales. Marine 
Biology, 161, 1087-1093. https://doi.org/10.1007/s00227-014-2401-2

519

520

521

522

523

524

11525

12526

13527

14527

15528

16529

17530

19531

20532

22533

23534

24535

26536

27537

28

29538

30539

31540

32541

34542

35543

36544

38545

39546

41547

42548

43549

445450

46551

47

${ }_{48} 552$

49553

50554

51

52555

53556

54557

55

56558

57559

58

59

60

Corkeron, P. J., Minton, G., Collins, T., Findlay, K., Willson, A., \& Baldwin, R. (2011). Spatial models of sparse data to inform cetacean conservation planning : an example from Oman. Endangered Species Research, 15, 39-52. https://doi.org/10.3354/esr00367

Cravatte, S., Kestenare, E., Eldin, G., Ganachaud, A., Lefevre, J., Marin, F., ... Aucan, J. (2015). Regional circulation around New Caledonia from two decades of observations. Journal of Marine Systems, 148, 249-271. https://doi.org/10.1016/j.jmarsys.2015.03.004

Currie, J. J., Stack, S. H., \& Kaufman, G. D. (2017). Modeling whale-vessel encounters: the role of speed in mitigating collisions with humpback whales (Megaptera novaeangliae). Journal of Cetacean Research and Management, 17, 57-63.

Derville, S., Torres, L. G., \& Garrigue, C. (2018). Social segregation of humpback whales in contrasted coastal and oceanic breeding habitats. Journal of Mammalogy, 99(1), 41-54. https://doi.org/10.1093/jmammal/gyx185

Derville, S., Torres, L. G., Iovan, C., \& Garrigue, C. (2018). Finding the right fit: Comparative cetacean distribution models using multiple data sources and statistical approaches. Diversity and Distribution, 24, 1657-1673. https://doi.org/10.1111/ddi.12782

Dransfield, a, Hines, E., McGowan, J., Holzman, B., Nur, N., Elliott, M., ... Jahncke, J. (2014). Where the whales are: using habitat modeling to support changes in shipping regulations within National Marine Sanctuaries in Central California. Endangered Species Research, 26(1), 39-57. https://doi.org/10.3354/esr00627

DTSI. (2016). Atlas bathymétrique de Nouvelle-Calédonie. Portail de l'information géographique de Nouvelle-Calédonie. http://www. geoportal.gouv.nc. Accessed February 2016.

Ducklow, H. W., Doney, S. C., \& Steinberg, D. K. (2009). Contributions of long-term research and time-series observations to marine ecology and biogeochemistry. Annual Review of Marine Science, 1, 279-302. https://doi.org/10.1146/annurev.marine.010908.163801

Faria, M. A., DeWeerdt, J., Pace, F., \& Mayer, F. X. (2013). Observation of a humpback whale (Megaptera Novaeangliae) birth in the coastal waters of Sainte marie Island, Madagascar. Aquatic Mammals, 39(3), 296-305. https://doi.org/10.1578/AM.39.3.2013.296

Friedman, J. H. (2001). Greedy Function Approximation: A gradient boosting machine. The Annals of Statistics, 29(5), 1189-1232. Retrieved from http://www.jstor.org/stable/2699986

Gabriele, C. M., Lockyer, C., Straley, J. M., Jurasz, C. M., \& Kato, H. (2010). Sighting history of a naturally marked humpback whale (Megaptera novaeangliae) suggests ear plug growth layer groups are deposited annually. Marine Mammal Science, 26(2), 443-450.

https://doi.org/10.1111/j.1748-7692.2009.00341.x

Gabriele, C. M., Neilson, J. L., Straley, J. M., Baker, C. S., Cedarleaf, J. A., \& Saracco, J. F. (2017). Natural history, population dynamics, and habitat use of humpback whales over 30 years on an Alaska feeding ground. Ecosphere, 8(1). https://doi.org/10.1002/ecs2.1641

Garrigue, C., Albertson, R., \& Jackson, J. A. (2012). An anomalous increase in the New Caledonia humpback whales breeding sub-stock E2. Report to the Scientific Committee of the International Whaling Commission, SC/64/SH6, 25.

Garrigue, C., Bonneville, C., Derville, S., Dodemont, R., Oremus, M., \& Pérard, V. (2017). Humpback whale offshore breeding grounds in the South Pacific: unravelling the network. 22th Biennial 
Conference on the Biology of Marine Mammals, Halifax, Canada.

Garrigue, C., Clapham, P. J., Geyer, Y., Kennedy, A. S., \& Zerbini, A. N. (2015). Satellite tracking reveals novel migratory patterns and the importance of seamounts for endangered South Pacific Humpback Whales. Royal Society Open Science, 2, 150489. https://doi.org/10.1098/rsos.150489

Garrigue, C., Dodemont, R., Steel, D., \& Baker, C. S. (2004). Organismal and "gametic" capturerecapture using microsatellite genotyping confirm low abundance and reproductive autonomy of humpback whales on the wintering grounds of New Caledonia. Marine Ecology Progress Series, 274, 251-262. https://doi.org/10.3354/meps274251

Garrigue, C., \& Gill, P. (1994). Observations of humpback whales Megaptera novaeangliae in New Caledonian waters during 1991-1993. Biological Conservation, 70, 211-218. https://doi.org/10.1016/0006-3207(94)90165-1

Garrigue, C., Greaves, J., \& Chambellant, M. (2001). Characteristics of the New Caledonian Humpback whale population. Memoirs of the Queensland Museum, 47(2), 69-75.

Giacoma, C., Papale, E., \& Azzolin, M. (2013). Are land based surveys a useful tool for managing marine species of coastal protected areas? Diversity, 5(1), 15-25. https://doi.org/10.3390/d5010015

Guisan, A., \& Zimmermann, N. E. (2000). Predictive habitat distribution models in ecology. Ecological Modelling, 135, 147-186. https://doi.org/10.1016/S0304-3800(00)00354-9

Hartman, K. L., Fernandez, M., \& Azevedo, J. M. N. (2014). Spatial segregation of calving and nursing Risso's dolphins (Grampus griseus) in the Azores, and its conservation implications. Marine Biology, 161(6), 1419-1428. https://doi.org/10.1007/s00227-014-2430-x

Hastie, T. J., \& Tibshirani, R. J. (1990). Generalized Additive Models, volume 43 of Monographs on Statistics and Applied Probability. London: Chapman and Hall/CRC. Retrieved from $\mathrm{http} / /$ books.google.com/books?hl=fr\&lr=\&id=qa29r1Ze1 coC\&pgis=1

Irvine, L. G., Thums, M., Hanson, C. E., Mcmahon, C. R., \& Hindell, M. A. (2017). Evidence for a widely expanded humpback whale calving range along the Western Australian coast. Marine Mammal Science, (Lockyer 1981), 1-17. https://doi.org/10.1111/mms.12456

IWC. (1998). Report of the sub-committee on comprehensive assessment of Southern Hemisphere humpback whales. Report of the Scientific Committee, Annex G. Report of the International Whaling Commission, Cambridge, 170-182.

Jackson, J. A., Ross-Gillespie, A., Butterworth, D., Findlay, K., Holloway, S., Robbins, J., ... Zerbini, A. (2015). Southern Hemisphere Humpback Whale Comprehensive Assessment - A synthesis and summary: 2005-2015. Report to the Scientific Committee of the International Whaling Commission, $\mathrm{SC} / 66 \mathrm{a} / \mathrm{SH} / \mathrm{,} \mathrm{1-38.}$

Laist, D. W., Knowlton, A. R., Mead, J. G., Collet, A. S., \& Podesta, M. (2001). Collisions Between Ships and Whales. Marine Mammal Science, 17(1), 35-75.

Lambert, C., Laran, S., David, L., Dorémus, G., Pettex, E., Van Canneyt, O., \& Ridoux, V. (2016). How does ocean seasonality drive habitat preferences of highly mobile top predators? Part I: the north-western Mediterranean Sea. Deep Sea Research Part II: Topical Studies in Oceanography. https://doi.org/10.1016/j.dsr2.2016.06.012

Lammers, M. O., Pack, A., \& Davis, L. (2007). Trends in whale/vessel collisions in Hawaiian waters. Report to the Scientific Committee of the International Whaling Commission, SC/59/BC14. 
602

603

604

605

606

607

608

11609

12610

13

14611

15612

16613

17

18614

19615

20616

21

22617

23618

24619

25

26620

27621

28622

29

30623

31624

32625

33626

34

35627

36628

37629

38630

40631

41632

42633

43

44634

45635

46636

48637

49638

50639

51640

53641

54642

55643

56643

57644

Lindenmayer, D. B., \& Likens, G. E. (2010). The science and application of ecological monitoring. Biological Conservation, 143(6), 1317-1328. https://doi.org/10.1016/j.biocon.2010.02.013

Lindsay, R., Constantine, R., Robbins, J., Mattila, D. K., Tagarino, A., \& Dennis, T. (2016). Characterising essential breeding habitat for whales informs the development of large-scale Marine Protected Areas in the South Pacific. Marine Ecology Progress Series, 548, 263-275. https://doi.org/10.3354/meps11663

Marchesiello, P., Lefèvre, J., Vega, A., Couvelard, X., \& Menkes, C. (2010). Coastal upwelling, circulation and heat balance around New Caledonia's barrier reef. Marine Pollution Bulletin, 61(7-12), 432-448. https://doi.org/10.1016/j.marpolbul.2010.06.043

Martins, C. C. a, Morete, M. E., Engel, M. H., Freitas, a. C., Secchi, E. R., \& Kinas, P. G. (2001). Aspects of habitat use patterns of humpback whales in the Abrolhos Bank, Brazil, breeding ground. Memoirs of the Queensland Museum, 47(2), 563-570.

McCullagh, P., \& Nelder, J. A. (1989). Generalized linear models. In Monographs on statistics and Applied Probability (2nd. editi). London: Chapman and Hall/CRC. Retrieved from http://www.popline.org/node/423879

Mercado III, E., \& Frazer, L. N. (1999). Environmental constraints on sound transmission by humpback whales. Journal of the Acoustical Society of America, 106(5), 3004-3016. https://doi.org/10.1121/1.423476

New, L. F., Hall, A. J., Harcourt, R., Kaufman, G., Parsons, E. C. M., Pearson, H. C., ... Schick, R. S. (2015). The modelling and assessment of whale-watching impacts. Ocean and Coastal Management, 115, 10-16. https://doi.org/10.1016/j.ocecoaman.2015.04.006

O'Connor, S., Campbell, R., Knowles, T., Cortez, H., \& Grey, F. (2009). Whale Watching Worldwide: Tourism numbers, expenditures and economic benefits - A special report from the International Fund for Animal Welfare. International Fund for Animal Welfare, 295. https://doi.org/10.2307/4444572

Olavarría, C., Baker, C. S., Garrigue, C., Poole, M., Hauser, N., Caballero, S., ... Russell, K. (2007). Population structure of South Pacific humpback whales and the origin of the eastern Polynesian breeding grounds. Marine Ecology Progress Series, 330, 257-268. https://doi.org/10.3354/meps330257

Orgeret, F., Garrigue, C., Gimenez, O., \& Pradel, R. (2014). Robust assessment of population trends in marine mammals applied to the New Caledonia Humpback Whales. Marine Ecology Progress Series, 515, 265-273. https://doi.org/10.3354/meps10992

Oviedo, L., \& Solís, M. (2008). Underwater topography determines critical breeding habitat for humpback whales near Osa Peninsula, Costa Rica : implications for Marine Protected Areas. Rev. Bio. Trop., 56, 591-602.

Pack, A. A., Herman, L. M., Craig, A. S., Spitz, S. S., Waterman, J. O., Herman, E. Y. K., ... Lowe, C. (2017). Habitat preferences by individual humpback whale mothers in the Hawaiian breeding grounds vary with the age and size of their calves. Animal Behaviour, 133, 131-144. https://doi.org/10.1016/j.anbehav.2017.09.012

Pierszalowski, S. P., Gabriele, C. M., Steel, D. J., Neilson, J. L., Vanselow, P. B. S., Cedarleaf, J. A., ... Baker, C. S. (2016). Local recruitment of humpback whales in Glacier Bay and Icy Strait, Alaska, over 30 years. Endangered Species Research, 31, 177-189. https://doi.org/10.3354/esr00761 
645

Pirotta, E., New, L., \& Marcoux, M. (2018). Modelling beluga habitat use and baseline exposure to shipping traffic to design effective protection against prospective industrialization in the Canadian Arctic. Aquatic Conservation: Marine and Freshwater Ecosystems, (July 2017), 1-10. https://doi.org/10.1002/aqc. 2892

Province Sud. (2009) Code de l'Environnement de la Province Sud. pp 322. Nouméa, NouvelleCalédonie. Retrieved from www.province-sud.nc.

Province Sud. (2013). Plan de gestion du Grand Lagon Sud 2013/2017. Province Sud, NouvelleCalédonie.

Province Sud. (2018). Charte d'Observation des Cétacés. https://www.provincesud.nc/sites/default/files/CHARTE\%20WW\%202018.pdf. Accessed July 2018.

QGIS Development Team. (2016). QGIS Geographic Information System. Open Source Geospatial Foundation Project. Version 2.18 La Palma. Retrieved from http://qgis.osgeo.org

R Core Team. (2016). $R$ : A language and environment for statistical computing. R Foundation for Statistical Computing, Vienna, Austria. Retrieved from http://www.r-project.org/.

Rasmussen, K., Palacios, D. M., Calambokidis, J., Saborío, M. T., Dalla Rosa, L., Secchi, E. R., ... Stone, G. S. (2007). Southern Hemisphere humpback whales wintering off Central America: insights from water temperature into the longest mammalian migration. Biology Letters, 3(3), 302-305. https://doi.org/10.1098/rsbl.2007.0067

Redfern, J. V., McKenna, M. F., Moore, T. J., Calambokidis, J., Deangelis, M. L., Becker, E. A., ... Chivers, S. J. (2013). Assessing the Risk of Ships Striking Large Whales in Marine Spatial Planning. Conservation Biology, 27(2), 292-302. https://doi.org/10.1111/cobi.12029

Riekkola, L., Zerbini, A. N., Andrews, O., Andrews-Goff, V., Baker, C. S., Chandler, D., ... Constantine, R. (2018). Application of a multi-disciplinary approach to reveal population structure and Southern Ocean feeding grounds of humpback whales. Ecological Indicators, 89(December 2017), 455-465. https://doi.org/10.1016/j.ecolind.2018.02.030

Robbins, J. (2007). Structure and dynamics of the Gulf of Maine humpback whale population. $\mathrm{PhD}$ Thesis, School of Biology, University of St. Andrews.

Rocha, J. R. C., Clapham, P. J., \& Ivashchenko, Y. (2015). Emptying the Oceans: A Summary of Industrial Whaling Catches in the 20th Century. Marine Fisheries Review, 76(4), 37-48. https://doi.org/10.7755/MFR.76.4.3

Scales, K. L., Miller, P. I., Hawkes, L. A., Ingram, S. N., Sims, D. W., \& Votier, S. C. (2014). On the front line: Frontal zones as priority at-sea conservation areas for mobile marine vertebrates. Journal of Applied Ecology, 51(6), 1575-1583. https://doi.org/10.1111/1365-2664.12330

Schaffar, A., Garrigue, C., \& Constantine, R. (2010). Exposure of humpback whales to unregulated whalewatching activities in their main reproductive area in New Caledonia. Journal of Cetacean Research and Management, 11(2), 147-152.

Schaffar, A., Madon, B., Garrigue, C., \& Constantine, R. (2013). Behavioural effects of whale watching activities on an endangered population of humpback whales wintering in New Caledonia. Endangered Species Research, 19, 245-254. https://doi.org/10.3354/esr00466

Senigaglia, V., Christiansen, F., Bejder, L., Gendron, D., Lundquist, D., Noren, D. P., ... Lusseau, D. (2016). Meta-analyses of whale-watching impact studies: Comparisons of cetacean responses to disturbance. Marine Ecology Progress Series, 542(January), 251-263. 


\section{https://doi.org/10.3354/meps11497}

Simmonds, M. P., \& Eliott, W. J. (2009). Climate change and cetaceans: concerns and recent developments. Journal of the Marine Biological Association of the United Kingdom, 89(01), 203210. https://doi.org/10.1017/S0025315408003196

Smith, J., Grantham, H., Gales, N., Double, M., Noad, M., \& Paton, D. (2012). Identification of humpback whale breeding and calving habitat in the Great Barrier Reef. Marine Ecology Progress Series, 447(Harwood 2001), 259-272. https://doi.org/10.3354/meps09462

Stamation, K. A., Croft, D. B., Shaughnessy, P. D., Waples, K. A., \& Briggs, S. V. (2010). Behavioral responses of humpback whales (Megaptera novaeangliae) to whale-watching vessels on the southeastern coast of Australia. Marine Mammal Science, 26(1), 98-122. https://doi.org/10.1111/j.1748-7692.2009.00320.x

Steel, D., Anderson, M., Garrigue, C., Olavarría, C., Caballero, S., Childerhouse, S., ... Baker, C. S. (2017). Migratory interchange of humpback whales (Megaptera novaeangliae) among breeding grounds of Oceania and connections to Antarctic feeding areas based on genotype matching. Polar Biology, 3(0123456789), 1-10. https://doi.org/10.1007/s00300-017-2226-9

Stockin, K. A., Weir, C. R., \& Pierce, G. J. (2006). Examining the importance of Aberdeenshire (UK) coastal waters for North Sea bottlenose dolphins (Tursiops truncatus). Journal of Marine Biological Association of the United Kingdom, 86, 201-207.

Sullivan, F. A., \& Torres, L. G. (2018). Assessment of vessel disturbance to gray whales to inform sustainable ecotourism. Journal of Wildlife Management, 82, 896-905. https://doi.org/10.1002/jwmg.21462

Sydeman, W. J., Poloczanska, E. S., Reed, T. E., \& Thompson, S. A. (2015). Climate change and marine vertebrates. Science, 350(6262), 171-193. https://doi.org/10.1126/science.aac9874

Taylor, B. L., Chivers, S. J., Larese, J., \& Perrin, W. F. (2007). Generation length and percent mature estimates for IUCN assessments of cetaceans. Administrative Report LJ-07-01 National Marine Fisheries, 24. https://doi.org/doi:10.1.1.530.4789

Thomas, P. O., Reeves, R. R., \& Brownell, R. L. (2015). Status of the world's baleen whales. Marine Mammal Science, 32(2), 682-734. https://doi.org/10.1111/mms.12281

Trudelle, L., Charrassin, J. B., Saloma, A., Pous, S., Kretzschmar, A., \& Adam, O. (2018). First insights on spatial and temporal distribution patterns of humpback whales in the breeding ground at Sainte Marie Channel, Madagascar. African Journal of Marine Science, 40(1), 75-86. https://doi.org/10.2989/1814232X.2018.1445028

UNESCO. (2009). Lagoons of New Caledonia: Reef Diversity and Associated Ecosystems. U.W.H. Centre. whc.unesco.org/en/list/1115/documents/ Accessed 2018-06-20. Retrieved from whc.unesco.org/en/list/1115/documents/

Wood, S. N. (2006). Generalized Additive Models: An Introduction with R. Chapman and Hall/CRC.

Worton, B. J. (1989). Kernel methods for estimating the utilization distribution in home-Range studies. Ecology, 70(1), 164-168. 


\section{TABLES}

Table 1: Summary of survey effort and observations of humpback whales at sea and from land in the South Lagoon, New Caledonia, from 1995 to 2017. (\#) indicates the number of humpback whale groups. "\# unique groups observed" is the sum of all the groups observed at sea and the groups observed from land only.

\begin{tabular}{|c|c|c|c|c|c|c|}
\hline year & $\begin{array}{l}\text { boat-based } \\
\text { effort (days) }\end{array}$ & $\begin{array}{l}\text { land-based } \\
\text { effort (days) }\end{array}$ & $\begin{array}{c}\text { \# groups } \\
\text { observed at sea }\end{array}$ & $\begin{array}{l}\text { \# groups } \\
\text { detected } \\
\text { from land }\end{array}$ & $\begin{array}{l}\text { \# groups } \\
\text { observed from } \\
\text { land only }\end{array}$ & $\begin{array}{l}\text { \# unique } \\
\text { groups } \\
\text { observed }\end{array}$ \\
\hline 1995 & 27 & 18 & 25 & 24 & 13 & 38 \\
\hline 1996 & 55 & 48 & 54 & 82 & 45 & 99 \\
\hline 1997 & 44 & 41 & 53 & 54 & 29 & 82 \\
\hline 1998 & 50 & 52 & 42 & 50 & 21 & 63 \\
\hline 1999 & 46 & 43 & 23 & 22 & 11 & 34 \\
\hline 2000 & 50 & 43 & 44 & 25 & 10 & 54 \\
\hline 2001 & 55 & 47 & 77 & 56 & 36 & 113 \\
\hline 2002 & 33 & 38 & 20 & 6 & 4 & 24 \\
\hline 2003 & 39 & 42 & 70 & 28 & 23 & 93 \\
\hline 2005 & 33 & 25 & 56 & 35 & 27 & 83 \\
\hline 2006 & 41 & 47 & 103 & 124 & 100 & 203 \\
\hline 2007 & 48 & 49 & 124 & 162 & 140 & 264 \\
\hline 2009 & 32 & 48 & 67 & 126 & 126 & 193 \\
\hline 2010 & 36 & 38 & 97 & 138 & 84 & 181 \\
\hline 2011 & 39 & 38 & 133 & 154 & 113 & 246 \\
\hline 2012 & 29 & 30 & 96 & 105 & 81 & 177 \\
\hline 2013 & 25 & 27 & 96 & 112 & 55 & 151 \\
\hline 2014 & 29 & 23 & 38 & 28 & 9 & 47 \\
\hline 2015 & 31 & 29 & 99 & 131 & 101 & 200 \\
\hline 2016 & 26 & 25 & 61 & 50 & 41 & 102 \\
\hline 2017 & 39 & 38 & 106 & 73 & 98 & 204 \\
\hline Total & 807 & 789 & 1,484 & 1,585 & 1,167 & 2,651 \\
\hline Mean & 38.4 & 37.6 & 70.7 & 75.5 & 55.6 & 126.2 \\
\hline SD & 9.5 & 9.9 & 33.4 & 49.5 & 43.5 & 74.2 \\
\hline
\end{tabular}


Table 2: Average proportion of humpback whale social group types observed across years at sea and from land in the South Lagoon, New Caledonia, from 1995 to 2017. Average proportion are indicated with \pm standard deviations. CG - represents Competitive Groups. From land, groups of more than 3 individuals with or without a calf were not distinguished, neither were singers from non-singing singletons. 
Table 3: Percentage of coverage of the humpback whale area of use by Marine Protected Areas in the New Caledonia South Lagoon. The area of use is estimated from the Kernel Density Estimates (KDE) presented in Figure 2a.

\begin{tabular}{lccc}
\hline & Province Park & UNESCO Heritage Zone & Merlet Reserve \\
\hline $\begin{array}{l}50 \% \text { KDE contour (core } \\
\text { area of use) }\end{array}$ & $100 \%$ & $38 \%$ & $0 \%$ \\
$\begin{array}{l}95 \% \text { KDE contour (general } \\
\text { area of use) }\end{array}$ & $100 \%$ & $55 \%$ & $2 \%$ \\
\hline
\end{tabular}




\section{FIGURES}

Figure 1: Map of New Caledonia (a) and the South Lagoon study area (b). Main currents are illustrated on the map based on Marchesiello et al. (2010) and Cravatte et al. (2015): ECC = East Caledonian Current; $\mathrm{VC}=$ Vauban Current; $\mathrm{ACNC}=$ Alis Current of New Caledonia. The ECC is a local branch of the larger scale South Equatorial Current. Upwellings and downwellings are represented with black curved arrows. Land is shown in black. Barrier and patch reef complexes in grey. The Province Park is shown with a black dashed line, the UNESCO World Heritage Zone with a black dotted line, and the Merlet Reserve with a black dashed and dotted line. Blue sail boats logos locate the harbours from which whale watching boat operators depart for daily trips (in Nouméa, and also mostly in Prony Bay). The mining Port of Goro inside the Prony Bay is shown with a red cargo logo. The zones with the most intense maritime traffic interpreted from records of the Automatic Identification System (AIS, www.marinetraffic.com) are delineated by a red polygon.

Figure 2: Map of humpback whale groups observed in the South Lagoon, New Caledonia, between 1995 and 2017: groups observed at sea $(a ; n=1,484)$ and groups observed from land only $(b ; n=1,167)$. The dotted lines represents the study area at sea and from land respectively. In panel (b), areas filled with dashes could not be observed from the land-based lookout, and represent $29 \%$ of encircled study area. Land is shown in black, barrier and patch reef complexes in grey. Isobaths are represented with light grey lines. The limits of the Merlet Reserve are indicated with a black dashed and dotted line.

Figure 3: Breeding season group encounter rates and social group types measured in the South Lagoon, New Caledonia, between 1995 and 2017. (a) Group encounter rates at sea $(n=1,484$ groups observed over 807 days), and (c) from land only ( $\mathrm{n}=1,150$ groups observed over 752 days during which survey effort duration was recorded), per hour of survey effort and per day. The lower and upper hinges of the boxplot correspond to the first and third quartiles. Proportions of social group types observed per year (\%) using each platform is represented in stacked colour bars: (b) at sea, and (d) from land.

Figure 4: Kernel density estimates (KDE) of humpback whale distribution in the South Lagoon, New Caledonia, between 1995 and 2017. (a) KDE based on unique observations at sea and from land over the whole study period $(n=2,651)$. KDE values below $5 \%$ are not shown. White lines delineate $10 \%$ contours of the KDE from $10 \%$ to $100 \%$. The $50 \%$ contour, or core area of use, is represented with a black line. (b) Overlap between 50\% contours of annual KDE (colours represent the numbers of years over which the grid cell was included in a 50\% contour). The black line delineates the area where more than 10 years of core areas overlap $\left(77 \mathrm{~km}^{2}\right)$. Observations are weighted proportionally to the number of individuals in 
the group and the amount of survey effort. Land is shown in black and reefs in grey. The Province Park is shown with a black dashed line, the UNESCO World Heritage Zone with a black dotted line, and the Merlet Reserve with a black dashed and dotted line.

Figure 5: Partial dependence plots modelling habitat selection of humpback whales from combined boatand land-based surveys in the South Lagoon, New Caledonia between 1995 and 2017. Predicted habitat suitability is shown on the y-axis with varying scales. Rug plots illustrate the distribution of values in the modelled dataset in percentiles.

Figure 6: Sea Surface Temperature (SST) in the South Lagoon, New Caledonia, averaged from MURSST (jplMURSST41, http://coastwatch.pfeg.noaa.gov/erdaap/) between July and August, 2002-2017. (a) Mean austral winter SST averaged across 16 years. (b) Coefficient of variation of SST calculated across 16 years. (c) Coefficient of variation of SST calculated across 3 months of austral winter and averaged over 16 years. Land is shown in black and reefs in grey. White lines delineate contours of the SST patterns.

\section{SUPPORTING INFORMATION}

S1: Estimating boat-based survey effort without GPS tracklines

S2: Estimating land-based survey effort 


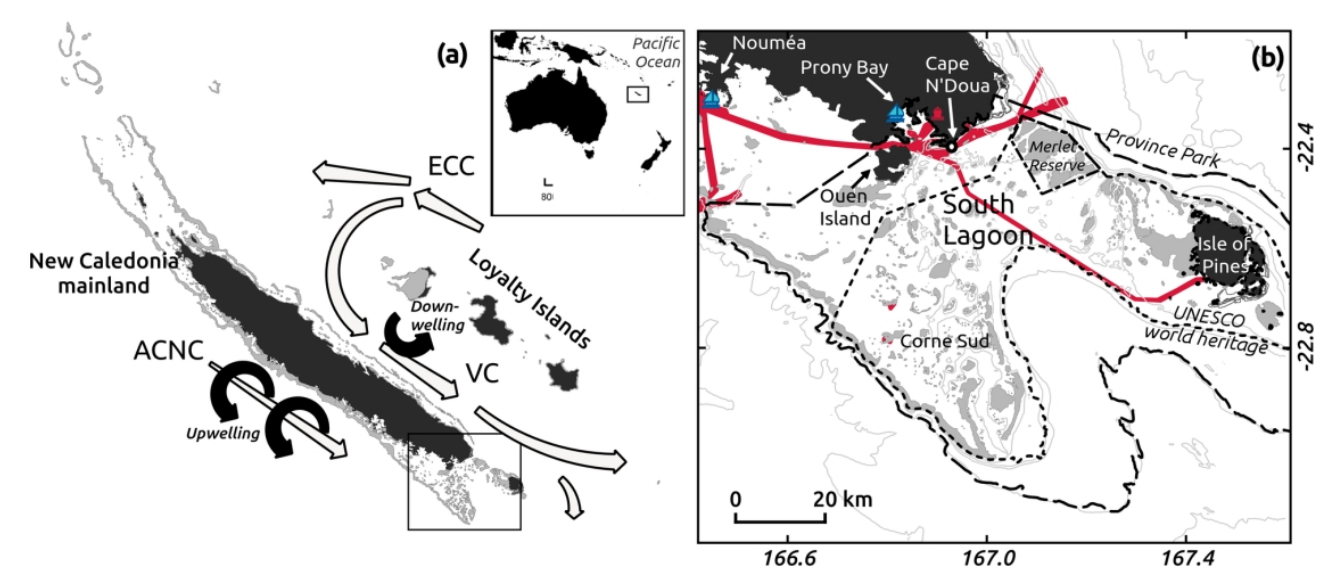

Figure 1

$168 \times 72 \mathrm{~mm}(300 \times 300 \mathrm{DPI})$ 

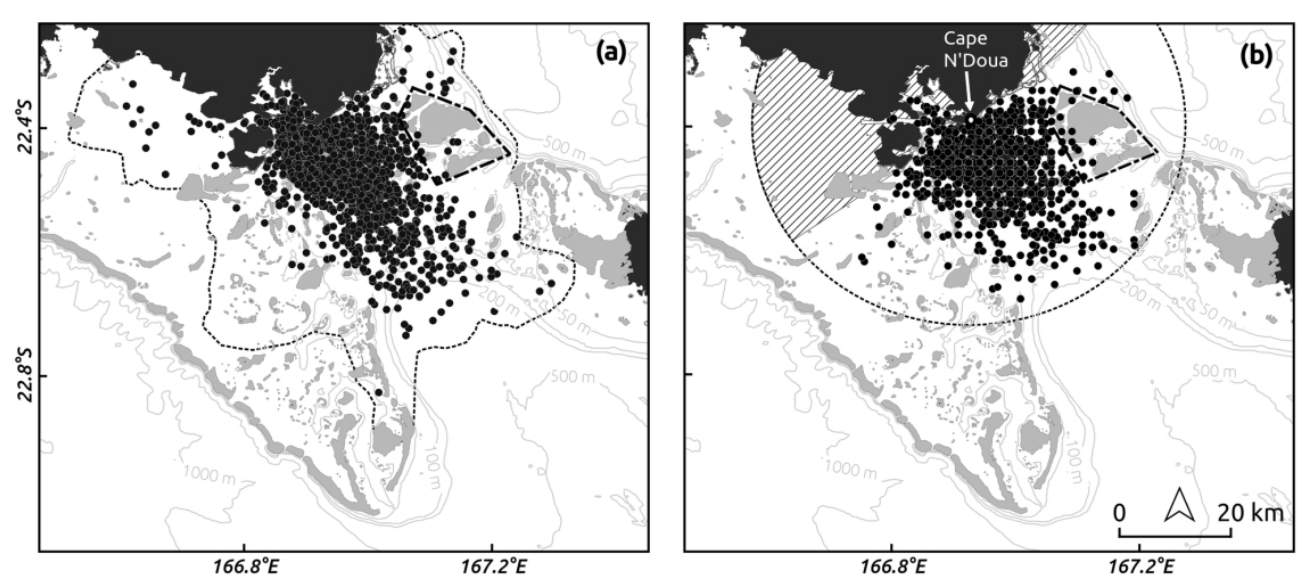

Figure 2

$168 \times 74 \mathrm{~mm}(300 \times 300$ DPI $)$ 


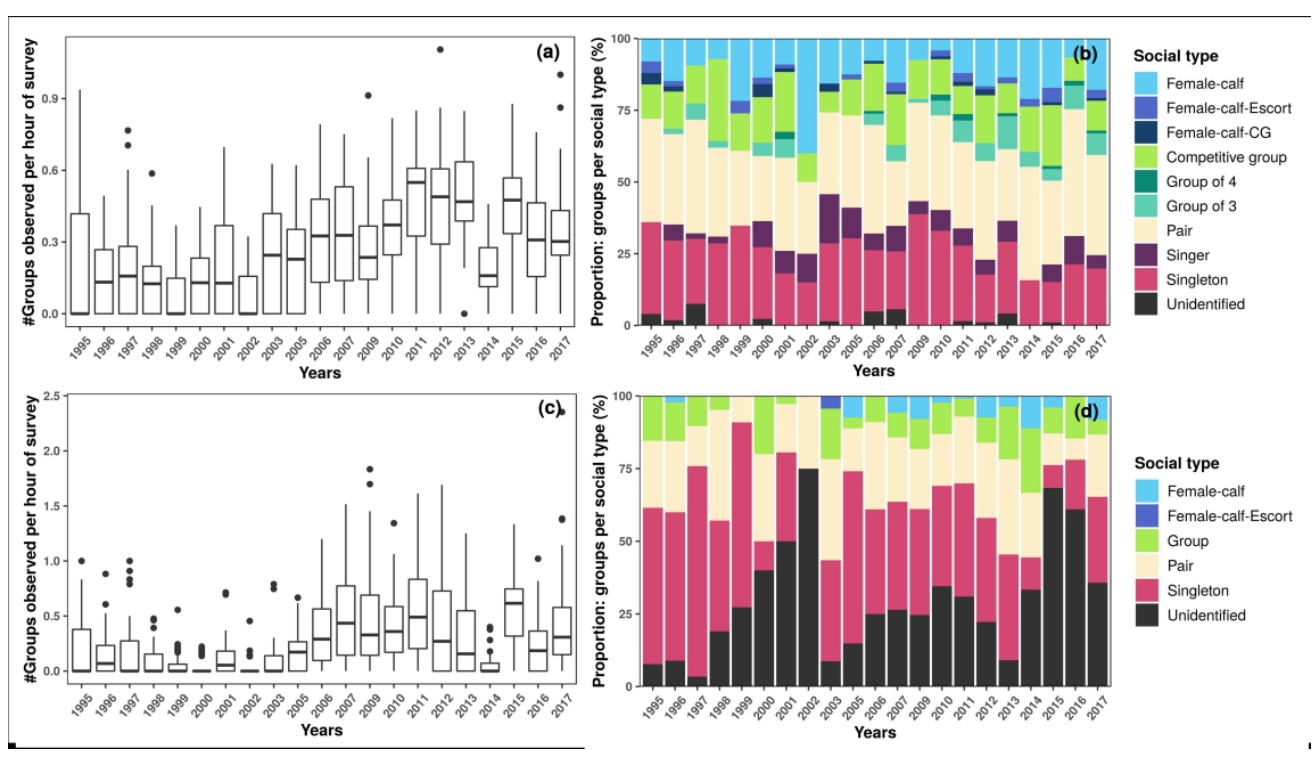

Figure 3

$319 \times 180 \mathrm{~mm}(300 \times 300 \mathrm{DPI})$ 


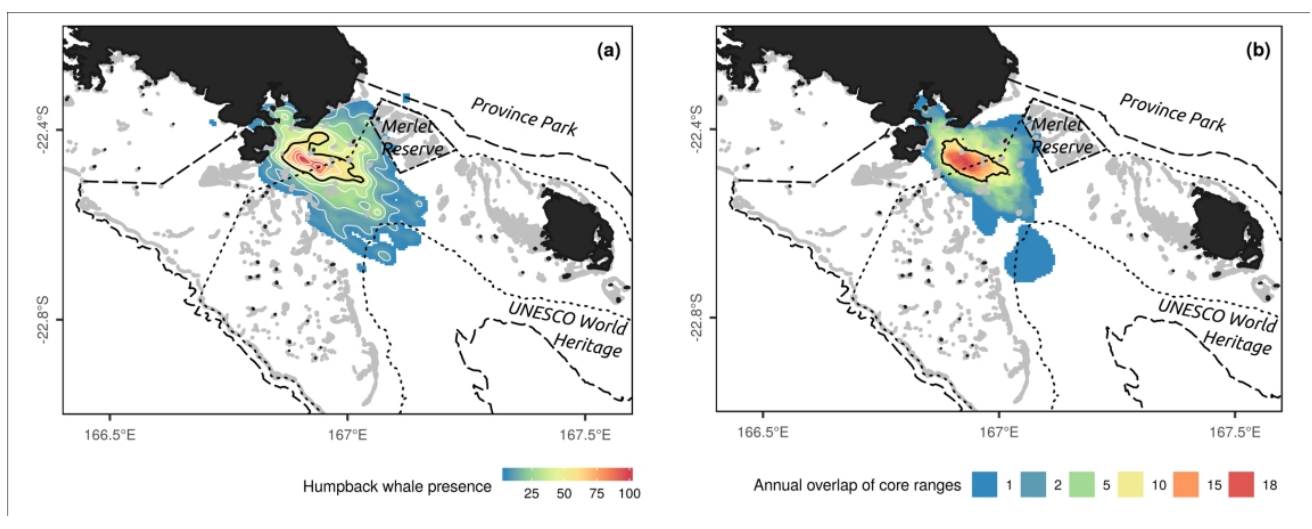

Figure 4

$203 \times 78 \mathrm{~mm}(300 \times 300$ DPI $)$

http://mc.manuscriptcentral.com/aqc 


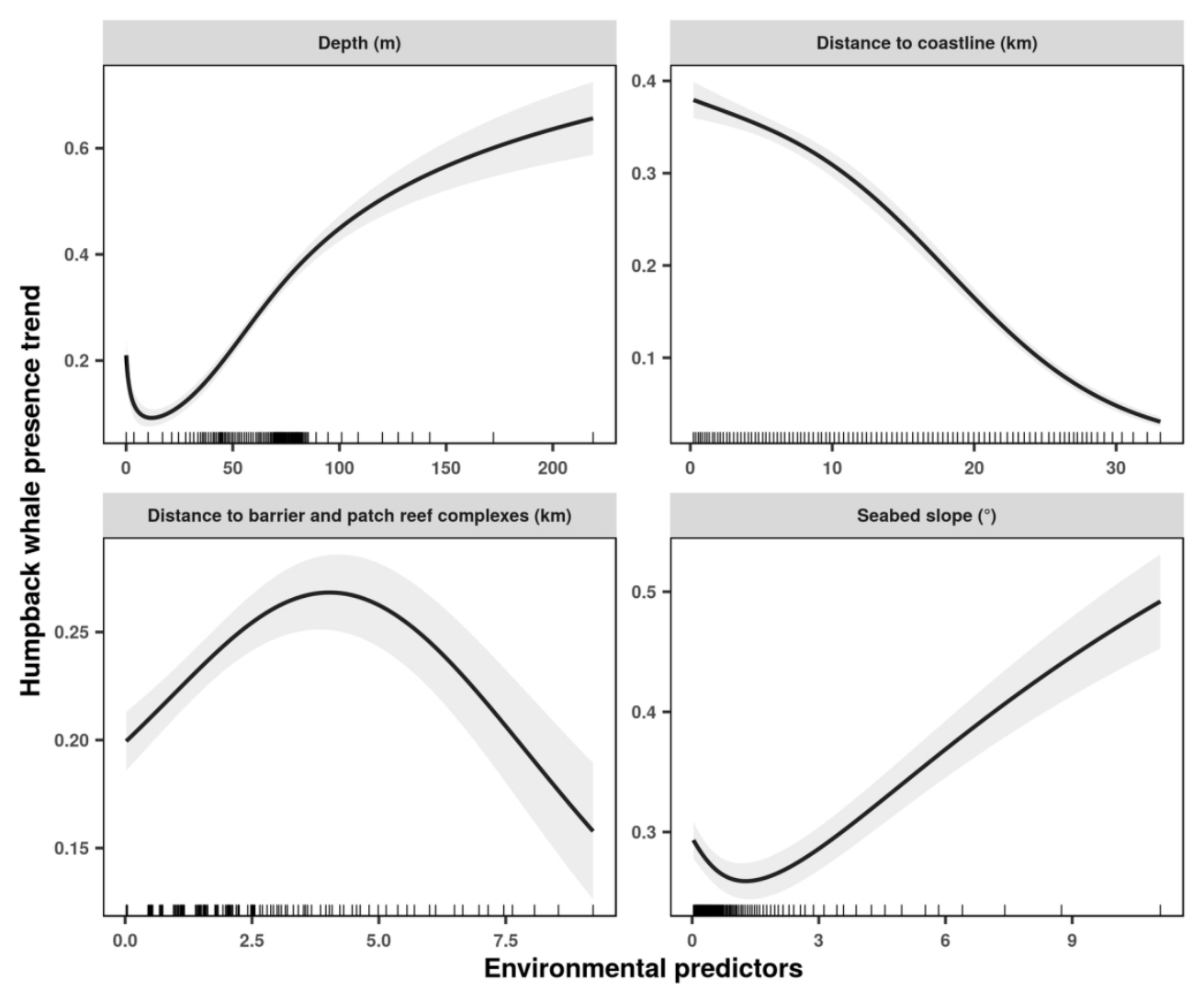

Figure 5

$152 \times 127 \mathrm{~mm}(300 \times 300 \mathrm{DPI})$ 


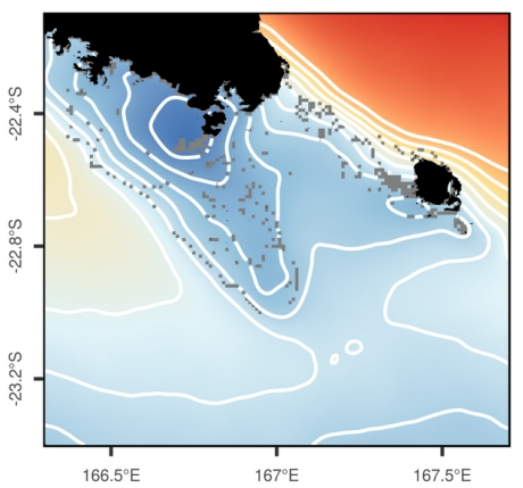

Average SST

$\left({ }^{\circ} \mathrm{C}\right)$

- 23.4

23.0

22.5

$-22.1$

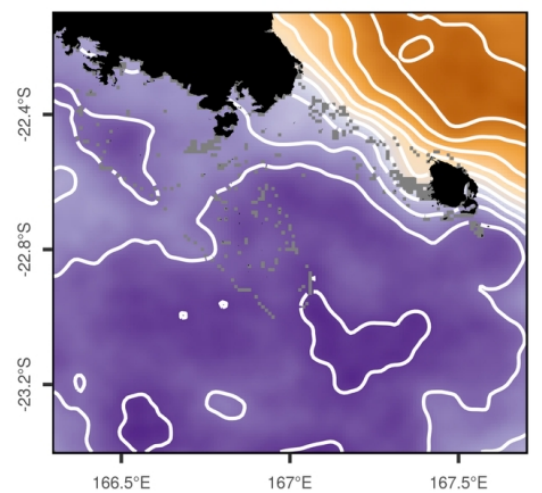

CV SST

between

season (\%)

$-2.50$

2.25

2.00

$-1.75$

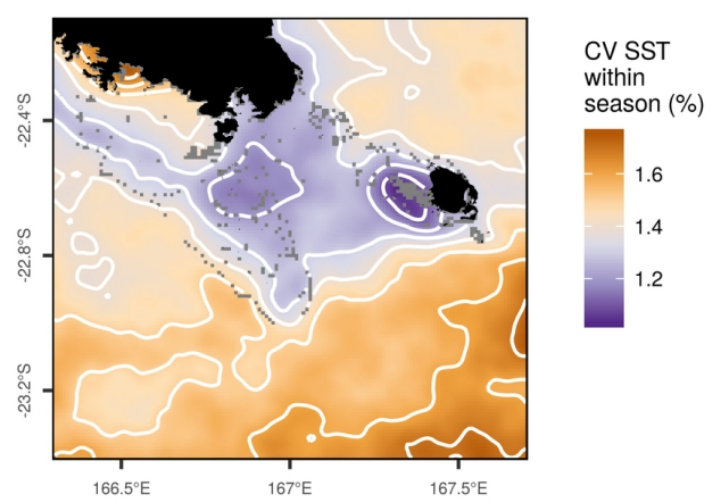

Figure 6

$78 \times 159 \mathrm{~mm}(300 \times 300$ DPI $)$ 